\title{
Influence of temperature on mycelial growth and number of sclerotia of Sclerotinia sclerotiorum the cause of Sclerotinia stem rot
}

\author{
Wpływ temperatury na wzrost grzybni i liczebność sklerocjów \\ Sclerotinia sclerotiorum - grzyba powodującego zgniliznę twardzikową
}

\author{
Andrzej Wójtowicz ${ }^{1 *}$, Ewa Jajor ${ }^{2}$, Marek Wójtowicz $^{3}$, Maria Pasternak $^{1}$
}

\begin{abstract}
Summary
The aim of the study was to determine the effect of temperature on mycelial growth of Sclerotinia sclerotiorum. Two isolates of the pathogen collected in 2014 in two southern regions of Poland were used in the experiments. Sclerotia of both isolates were placed on PDA (Potato Dextrose Agar) medium in Petri dishes and incubated at 10,15, 20 and $25^{\circ} \mathrm{C}$ and number of days taken by mycelium to fill Petri plate were recorded. Differentiating effect of isolate and temperature was observed in the study. The slowest mycelial growth was observed at $10^{\circ} \mathrm{C}$ while the fastest at $25^{\circ} \mathrm{C}$. Results of experiments were also used for determination of temperature on mycelial growth with the use of exponential models.
\end{abstract}

Key words: temperature; Sclerotinia sclerotiorum; sclerocja

\section{Streszczenie}

Celem przeprowadzonych doświadczeń było określenie wpływu temperatury na wzrost grzybni Sclerotinia sclerotiorum - sprawcy zgnilizny twardzikowej. W badaniach zastosowano wybrane izolaty S. sclerotiorum, pochodzące z porażonych w roku 2014 roślin rzepaku ozimego w województwach: opolskim i małopolskim. Sklerocja izolatów umieszczano na pożywce PDA (Potato Dextrose Agar) w temperaturze: $10,15,20$ i $25^{\circ} \mathrm{C}$ i obserwowano wzrost patogena do dnia, w którym stwierdzano zetknięcie grzybni z krawędzią płytki. Na podstawie uzyskanych wyników wykazano różnicujący wpływ temperatury oraz izolatu na wzrost grzybni S. sclerotiorum. Najwolniejszy wzrost odnotowano w temperaturze $10^{\circ} \mathrm{C}$, a najszybszy w temperaturze $25^{\circ} \mathrm{C}$. Wyniki przeprowadzonych doświadczeń wykorzystano do matematycznego opracowania wpływu temperatury na rozwój i wzrost $S$. sclerotiorum za pomocą równań wykładniczych.

Słowa kluczowe: temperatura; Sclerotinia sclerotiorum; sclerocjum

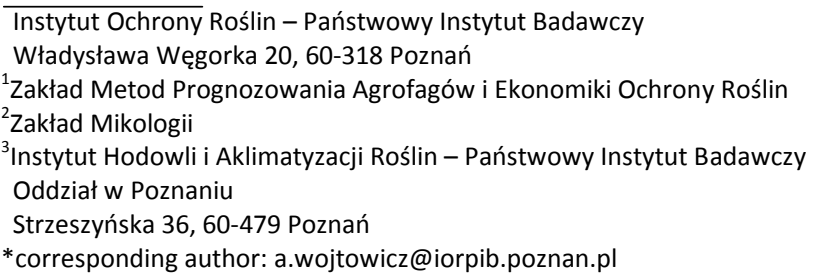




\section{Wstęp / Introduction}

Sclerotinia sclerotiorum (Lib.) de Bary występuje powszechnie na wielu kontynentach i charakteryzuje się bardzo szerokim zakresem roślin gospodarzy. Poraża około 400 gatunków roślin (Purdy 1979). Stanowi poważne zagrożenie dla roślin uprawnych o dużym znaczeniu gospodarczym, takich jak: słonecznik, ziemniak, tytoń, pomidor, rośliny $\mathrm{z}$ rodziny bobowatych oraz kapustowatych, w tym rzepak (Boland i Hall 1994; Hegedus i Rimmer 2005; Rimmer i wsp. 2007). Straty w plonach wywołane porażeniem roślin przez $S$. sclerotiorum uzależnione są od stopnia podatności odmian oraz przebiegu warunków meteorologicznych, z których temperatura, obok opadów oraz wilgotności powietrza i gleby odgrywa kluczową rolę (Koch i wsp. 2007; Wu i Subbarao 2008; Wu i wsp. 2008). Wśród doniesień naukowych na temat wpływu temperatury na rozwój grzybni $S$. sclerotiorum przeważają opracowania pochodzące z 20. wieku (Coe 1944; Morgan 1952; Cappellini 1960; Porth 1966; Abawi i Grogan 1975). W ostatnim dziesięcioleciu liczba publikacji uwzględniających tę tematykę jest znacznie skromniejsza (Bolton i wsp. 2006). Występują ponadto różnice w opiniach na temat optymalnej temperatury warunkującej przyrost grzybni. Według jednych optymalna temperatura dla rozwoju grzybni $S$. sclerotiorum nie przekracza $20^{\circ} \mathrm{C}$ (Coe 1944; Morgan 1952), natomiast autorzy nowszych prac uważają, że jest zbliżona do $25^{\circ} \mathrm{C}$ (Cuong i Dohroo 2006; Hoyte 2012). W związku z powyższym oraz z powodu braku informacji o wpływie temperatury na rozwój grzybni występujących w Polsce izolatów S. sclerotiorum zasadnym wydaje się ponowne podjęcie tej tematyki.

Celem pracy było określenie w warunkach kontrolowanych wpływu temperatury na wzrost grzybni oraz liczebność sklerocjów $S$. sclerotiorum.

\section{Materiały i metody / Materials and methods}

Ze zgromadzonych w Zakładzie Mikologii Instytutu Ochrony Roślin - Państwowego Instytutu Badawczego w Poznaniu kilkudziesięciu kultur grzyba S. sclerotiorum pochodzących z różnych rejonów uprawy rzepaku w Polsce, do doświadczeń wybrano dwa izolaty. Wytypowano je na podstawie zróżnicowania pod względem budowy morfologicznej grzybni powietrznej i tempa wzrostu na pożywce PDA (Potato Dextrose Agar, Difco) oraz patogeniczności. Pierwszy izolat charakteryzował się bardzo obfitą, szybko rosnącą grzybnią, natomiast drugi izolat rósł na pożywce wolniej, a jego grzybnia powietrzna była bardzo uboga. Użyte w badaniu izolaty w przeprowadzonych wcześniej testach $\mathrm{z}$ zakażaniem roślin rzepaku wyróżniały się wysoką patogenicznością. Izolaty zostały zebrane z roślin rzepaku ozimego w roku 2014 w miejscowości Kubice, województwo opolskie (izolat 1) oraz W miejscowości Sidzina, województwo małopolskie (izolat 2). Izolaty inkubowano $\mathrm{w}$ temperaturze $18^{\circ} \mathrm{C}$ (Cappelli i wsp. 1998), przez 15 dni na pożywce PDA w celu uzyskania sklerocjów S. sclerotiorum. Powstałe sklerocja pobierano, następnie odkażano przez 1 minutę w 5\% roztworze podchlorynu sodu i płukano pod bieżącą wodą. Po osuszeniu sklerocja wykładano w centralnym punkcie szalki Petriego o średnicy $90 \mathrm{~mm}$, gdzie wcześniej rozlano pożywkę PDA w ilości $20 \mathrm{ml}$ na płytkę. Płytki inkubowano $\mathrm{w}$ komorach fitotronowych, bez dostępu światła, przy 4 różnych wartościach temperatur: 10, 15, 20 i $25^{\circ} \mathrm{C}$. W każdej $\mathrm{z}$ badanych temperatur oceniano wzrost grzybni analizowanych izolatów na pięciu płytkach Petriego. W okresie od umieszczenia sklerocjów na pożywce PDA do dnia, w którym następowało zetknięcie grzybni z krawędzią płytki Petriego, co 24 godziny mierzono średnicę przyrastającej grzybni z dokładnością do $1 \mathrm{~mm}$. Pomiary średnicy kolonii wykonywano każdorazowo według dwóch prostopadłych linii. Wykonano cztery serie doświadczeń. Wyniki opracowano statystycznie, $\mathrm{z}$ zastosowaniem regresji oraz analizy wariancji, a istotność różnic oszacowano na poziomie 0,05 .

\section{Wyniki i dyskusja / Results and discussion}

Na podstawie przeprowadzonych doświadczeń wykazano różnicujący wpływ temperatury i izolatu na wzrost grzybni S. sclerotiorum (tab. 1). Średnia liczba dni od umieszczenia sklerocjów izolatu 1 na pożywce do dnia, w którym średnica grzybni osiągnęła krawędź płytki wynosiła 5,4 dni i była istotnie mniejsza o średnio 0,5 dnia od liczby dni, w których występował wzrost grzybni izolatu 2 (6,1 dni). Temperatura również miała wpływ i modyfikowała wzrost grzybni badanego patogena. Najwolniejszy wzrost grzybni S. sclerotiorum odnotowano w temperaturze $10^{\circ} \mathrm{C}$. W tych warunkach średnia liczba dni od umieszczenia sklerocjów na pożywce do dnia, w którym grzybnia docierała do krawędzi płytki wynosiła 9,3 dnia i była istotnie wyższa od zarejestrowanej w pozostałych temperaturach prowadzenia doświadczenia. Podwyższenie temperatury do $15^{\circ} \mathrm{C}$ skutkowało istotnym skróceniem analizowanego okresu rozwoju grzybni obu izolatów do 5,5 dnia. Uzyskany w tych warunkach wynik był istotnie wyższy od rezultatów odnotowanych w temperaturach 20 i $25^{\circ} \mathrm{C}$, które nie różniły się statystycznie i wynosiły odpowiednio 4,4 i 3,6 dnia.

Wyniki przeprowadzonych doświadczeń wykorzystano do matematycznego opracowania wpływu temperatury na rozwój grzybni S. sclerotiorum za pomocą następujących równań:

$$
\begin{array}{ll}
\mathrm{LdA}=3,351+\exp (3,793+(-0,212) \times \mathrm{T}) & \left(\mathrm{R}^{2}=0,90\right) \\
\mathrm{LdB}=3,581+\exp (3,826+(-0,198) \times \mathrm{T}) & \left(\mathrm{R}^{2}=0,93\right)
\end{array}
$$

LdA - liczba dni od umieszczenia sklerocjów na pożywce do dnia, w którym grzybnia izolatu 1 osiąga średnicę $9 \mathrm{~cm}$, LdB - liczba dni od umieszczenia sklerocjów na pożywce do dnia, w którym grzybnia izolatu 2 osiąga średnicę $9 \mathrm{~cm}$, $\mathrm{T}$ - temperatura,

$\mathrm{R}^{2}$ - współczynnik determinacji.

Wykazane w niniejszej pracy zróżnicowanie wzrostu grzybni izolatów S. sclerotiorum koresponduje z wynikami przedstawionymi przez Wu i Subbarao (2008), którzy odnotowali istotne różnice w karpogenicznym kiełkowaniu sklerocjów dwóch badanych izolatów tego patogena. Szeroko zakrojone badania w tym zakresie przeprowadzili Irani i wsp. (2011), którzy porównali 186 izolatów 
Tabela 1. Wpływ temperatury i izolatu Sclerotinia sclerotiorum na liczbę dni (średnio) potrzebną na przerośnięcie przez grzybnię całej powierzchni płytki Petrirgo

Table1. Effect of isolate of Sclerotinia sclerotiorum and temperature on number of days taken by mycelium to fill Petri plate

\begin{tabular}{l|c|c|c|r|c}
\hline \multirow{2}{*}{$\begin{array}{c}\text { Doświadczenie } \\
\text { Experiment }\end{array}$} & \multicolumn{5}{|c}{ Temperatura - Temperature / Dni - Days } \\
\cline { 2 - 6 } & $25^{\circ} \mathrm{C}$ & $20^{\circ} \mathrm{C}$ & $15^{\circ} \mathrm{C}$ & $10^{\circ} \mathrm{C}$ & średnio - mean \\
\hline Izolat 1- Izolate 1 & 3,5 & 4,2 & 5,1 & 8,7 & $5,4 \mathrm{a}$ \\
\hline Izolat 2 - Izolate 2 & 3,8 & 4,7 & 5,9 & 10,0 & $6,1 \mathrm{~b}$ \\
\hline Średnio - Mean & $3,6 \mathrm{~A}$ & $4,4 \mathrm{~A}$ & $5,5 \mathrm{~B}$ & $9,3 \mathrm{C}$ & \\
\hline
\end{tabular}

Średnie oznaczone tą samą literą nie różnią się istotnie według testu Tukeya $(\mathrm{p}=0,05)$. Małe litery zastosowano do wyrażenia różnic w wierszach. Duże do wyrażenia różnic w kolumnach

Means followed by the same letter are not significantly different according to Tukey's test $(p=0.05)$. Significance of data differences in row are expressed by small letters. Significance of data differences in column are expressed by capital letters

Tabela 2. Wpływ temperatury i izolatu Sclerotinia sclerotiorum na średnią liczbę uzyskanych sklerocjów

Table 2. Effect of isolate of Sclerotinia sclerotiorum and temperature on number of sclerotia

\begin{tabular}{l|l|c|c|c|c}
\hline \multirow{2}{*}{$\begin{array}{c}\text { Doświadczenie } \\
\text { Experiment }\end{array}$} & \multicolumn{5}{|c}{ Temperatura - Temperature / Liczba sklerocjów - Number of sclerotia } \\
\cline { 2 - 6 } & $25^{\circ} \mathrm{C}$ & $20^{\circ} \mathrm{C}$ & $15^{\circ} \mathrm{C}$ & $10^{\circ} \mathrm{C}$ & średnio - mean \\
\hline Izolat 1 - Izolate 1 & 27,7 & 30,8 & 27,2 & 13,1 & $24,7 \mathrm{a}$ \\
\hline Izolat 2 - Izolate 2 & 25,9 & 24,9 & 22,0 & 12,1 & $21,2 \mathrm{a}$ \\
\hline Średnio - Mean & $26,8 \mathrm{~B}$ & $27,8 \mathrm{~B}$ & $24,6 \mathrm{~B}$ & $12,6 \mathrm{~A}$ & \\
\hline
\end{tabular}

Średnie oznaczone tą samą literą nie różnią się istotnie według testu Tukeya $(\mathrm{p}=0,05)$. Małe litery zastosowano do wyrażenia różnic $\mathrm{w}$ wierszach. Duże do wyrażenia różnic w kolumnach

Means followed by the same letter are not significantly different according to Tukey's test $(\mathrm{p}=0.05)$. Significance of data differences in row are expressed by small letters. Significance of data differences in column are expressed by capital letters

S. sclerotiorum pochodzących z Azerberjdżanu oraz Iranu i wykazali różnicujący wpływ izolatu na tempo wzrostu grzybni tego patogena. Hoyte (2012) natomiast wśród 13 badanych izolatów $S$. sclerotiorum zaobserwował 12 nieróżniących się istotnie pod względem wzrostu grzybni.

Przedstawione w pracy wyniki badań nad wpływem temperatury na wzrost grzybni $S$. sclerotiorum są zgodne z rezultatami doświadczeń Cuonga i Dohroo (2006), którzy analizując czas od nałożenia fragmentów grzybni $S$. sclerotiorum na pożywkę PDA do osiągnięcia przez grzybnię $9 \mathrm{~cm}$ średnicy $\mathrm{w}$ temperaturze wynoszącej: 10,15 , 20 i $25^{\circ} \mathrm{C}$ odnotowali odpowiednio następujące wyniki: 10, 7, 5, 4 dni. Podobne rezultaty badań zaprezentowali Cappellini (1960) oraz Abawi i Grogan (1975), którzy wykazali największy przyrost grzybni w temperaturze 20 i $25^{\circ} \mathrm{C}$. Natomiast w doświadczeniach Coea (1944) i Morgana (1952) optymalna temperatura przyrostu grzybni $S$. sclerotiorum mieściła się odpowiednio w zakresie $19-20^{\circ} \mathrm{C}$ oraz $15,5-20^{\circ} \mathrm{C}$. Interesujace wyniki badań ukierunkowanych na określenie wpływu temperatury na wzrost grzybni S. sclerotiorum przedstawił Porth (1966), który porównał przyrost suchej masy grzybni w temperaturze 16,20 oraz $24^{\circ} \mathrm{C}$ i wykazal, że ósmego dnia od umieszczenia grzybni na pożywce w temperaturze $24^{\circ} \mathrm{C}$ sucha masa grzybni była 1,5 i 13 razy większa od uzyskanej $\mathrm{w}$ eksperymentach prowadzonych odpowiednio w temperaturze 20 i $16^{\circ} \mathrm{C}$. Mikić i wsp. (2014) porównując wpływ temperatury wynoszącej 15,22 i $30^{\circ} \mathrm{C}$ na wzrost $S$. sclerotiorum na pożywce PDA odnotowali istotne różnice w rozwoju grzybni w zastosowanych temperaturach. Najszybszy przyrost grzybni wystapił w temperaturze $22^{\circ} \mathrm{C}$, a najwolniejszy w temperaturze $30^{\circ} \mathrm{C}$. Istotny związek rozwoju grzybni $S$. sclerotiorum z temperatura stwierdził również Hoyte (2012), który z zastosowaniem modelu termodynamicznego określił wartość optymalnej temperatury rozwoju grzybni zastosowanego w badaniach izolatu S. sclerotiorum wynosząca $24,2^{\circ} \mathrm{C}$. Różnicujący wpływ temperatury na wzrost grzybni $S$. sclerotiorum potwierdzili również Wu i wsp. (2008), którzy wykazali przyspieszenie rozwoju grzybni w następstwie podwyższania temperatury w zakresie od 5 do $25^{\circ} \mathrm{C}$ oraz zwolnienie analizowanego procesu $\mathrm{w}$ efekcie zastosowania temperatury wynoszącej $30^{\circ} \mathrm{C}$. $\mathrm{Na}$ podstawie wyników tych doświadczeń Wu i wsp. (2008) zaproponowali wielomian drugiego stopnia do opisania wpływu temperatury na przyrost grzybni w okresie 24 godzin od umieszczenia grzybni na pożywce. Nieliniowy charakter przyrostu grzybni S. sclerotiorum wykazany przez Wu i wsp. (2008) oraz Hoyte (2012) koresponduje z matematycznym opisem analizowanych czynników przedstawionym w niniejszej pracy z wykorzystaniem równania wykładniczego.

Przeprowadzone obliczenia statystyczne wykazały również różnicujący wpływ temperatury na liczbę sklerocjów badanego patogena (tab. 2). Najwięcej sklerocjów (średnio 24,6-26,8 sztuk) uzyskano w temperaturze odpowiednio $15-25^{\circ} \mathrm{C}$. Mniej o połowę tych form przetrwalnikowych (średnio 12,6 sztuk) powstało w temperaturze $10^{\circ} \mathrm{C}$, a ich liczba różniła się istotnie od stwierdzonych w doświadczeniach przeprowadzonych przy wyższych wartościach temperatur. Wykazany na podstawie wyników przeprowadzonych eksperymentów wpływ temperatury na liczbę sklerocjów wskazuje na rosnące prawdopodobieństwo pogorszenia stanu fitosanitarnego gleby i zwiększenia zagrożenia roślin żywicielskich porażeniem przez 
S. sclerotiorum w następstwie przewidywanego ocieplenia klimatu.

W przeprowadzonych badaniach nie stwierdzono różnic w liczbie sklerocjów między badanymi izolatami. Uzyskane wyniki są w części zgodne z rezultatami badań Cuonga i Dohroo (2006), którzy porównali liczbę sklerocjów w temperaturze: $5,10,15,20$ oraz $25^{\circ} \mathrm{C}$ i nie wykazali istotnych różnic między wynikami eksperymentów przeprowadzonych $\mathrm{w}$ temperaturze w zakresie od 10 do $25^{\circ} \mathrm{C}$. Podobne rezultaty badań przedstawili Abawi i Grogan (1975), którzy stwierdzili największą liczebność sklerocjów w temperaturze 20 i $25^{\circ} \mathrm{C}$.

Wykazany w pracy wpływ podwyższenia temperatury w zakresie $10-25^{\circ} \mathrm{C}$ na $S$. sclerotiorum pozwala zakładać, że przewidywane zmiany warunków klimatycznych będą oddziaływać stymulująco na rozwój tego patogena, co jest zgodne $\mathrm{z}$ tezami prezentowanymi przez Siebold i Tiedemanna (2012), którzy prognozują wcześniejsze o 5-7 dni kiełkowanie sklerocjów na wiosnę w następstwie podwyższenia temperatury o $2^{\circ} \mathrm{C}$.

Omawiając znaczenie ocieplenia klimatu Siebold i Tiedemann (2012) zwracają jednocześnie uwagę na dominującą rolę warunków wilgotnościowych w kształtowaniu zasięgu i nasilenia zgnilizny twardzikowej. Powyższa opinia jest zbieżna z wynikami Wu i Subbarao (2008), którzy wykazali istotny wzrost liczby kiełkujących sklerocjów w efekcie podwyższenia potencjału wodnego $\mathrm{z}-0,3$ do $-0,01 \mathrm{MPa}$. Podsumowując rozważania na temat wpływu ocieplenia klimatu na zagrożenie rzepaku przez S. sclerotiorum można zakładać wzrost znaczenia zgnilizny twardzikowej, zwłaszcza w sezonach charakteryzujących się warunkami wilgotnościowymi spełniającymi wymagania patogena.

\section{Wnioski / Conclusions}

1. Odnotowany w doświadczeniach wpływ temperatury otoczenia na wzrost grzybni i liczebność sklerocjów S. sclerotiorum wskazuje na znaczenie temperatury w epidemiologii zgnilizny twardzikowej.

2. Wysoka wartość współczynnika determinacji równań matematycznych opisujących wpływ temperatury na wzrost grzybni $S$. sclerotiorum świadczy o dobrym dopasowaniu opracowanych modeli do danych empirycznych.

3. Uzyskane wyniki pozwalają prognozować szybsze tempo wzrostu grzybni S. sclerotiorum w następstwie przewidywanego podwyższenia temperatury otoczenia.

\section{Literatura / References}

Abawi G.S., Grogan R.G. 1975. Source of primary inoculum and effects of temperature and moisture on infection of beans by Whetzelinia sclerotiorum. Phytopathology 65: 300-309.

Boland G.J., Hall R. 1994. Index of plant hosts of Sclerotinia sclerotiorum. Canadian Journal of Plant Pathology 16 (2): $93-108$.

Bolton M.D., Thoma B.P.H.J., Nelson B.D. 2006. Sclerotinia sclerotiorum (Lib) de Bary: biology and molecular traits of a cosmopolitan pathogen. Molecular Plant Pathology 7 (1): 1-16.

Cappellini R.A. 1960. Field inoculation of forage legumes and temperature studies with isolates od Sclerotinia trifoliorum and S. sclerotiorum. Plant Disease Reporter 44: 862-864.

Cappelli C., Winter W., Paul V.H. 1998. Detection of seed-transmitted pathogens of rape (Brassica napus ssp. oleifera D.C.). IOBC/WPRS Bulletin 21 (5): 1-13.

Coe D.M. 1944. Variations in single ascospore isolates of Sclerotinia sclerotiorum. Mycologia 36: 235-241.

Cuong N.D., Dohroo N.P. 2006. Morphological, cultural and physiological studies on Sclerotinia sclerotiorum causing stalk rot of cauliflower. Omonrice 14: 71-77.

Hegedus D.D., Rimmer S.R. 2005. Sclerotinia sclerotiorum: when "to be or not to be" a pathogen? FEMS Microbiology Letters 251 (2): $177-184$.

Hoyte S.M. 2012. Epidemiology and management of Sclerotinia sclerotiorum (Lib.) de Bary in kiwifruit (Actinidia deliciosa (A. Chev.)) http://mro.massey.ac.nz/bitstream/handle/10179/3768/02_whole.pdf?sequence=1 [Accessed: 12.10.2015].

Irani H., Heydari A., Javan-Nikkhah M., Ibrahimow A. 2011. Pathogenicity variation and mycelial compatibility groups in Sclerotinia sclerotiorum. Journal of Plant Protection Research 51 (4): 329-336.

Koch S., Dunker S., Kleinhenz B., Rohrig M., Tiedemann A. 2007. Crop loss-related forecasting model for Sclerotinia stem rot in winter oilseed rape. Phytopathology 97 (9): 1186-1194.

Mikić I., Radan Z., Cosić J., Vrandećić K. 2014. The influence of nutrition media and temperature on Sclerotinia sclerotiorum development. Poljoprivreda 20 (2): 8-11.

Morgan C.D. Jr. 1952. Corelation of the growth rate of 23 Sclerotinia isolates in vitro with the rate of infectivity in five hosts at five different temperatures. Phytopathology 42, p. 471.

Porth R.B. 1966. Factors affecting the growth and pathogenicity of Sclerotinia sclerotiorum. (Lib.) de Bary. The University of British Columbia, 99 pp.

Purdy L.H. 1979. Sclerotinia sclerotiorum: History, diseases and symptomatology, host range, geographic distribution and impact. 1. Phytopathology 69 (8): 875-880.

Rimmer S.R., Shattuck V.I., Buchwaldt L. 2007. Compendium of Brassica Diseases. The APS, St. Paul, MN, 117 pp.

Siebold M., Tiedemann A. 2012. Potential effects of global warming on oilseed rape pathogens in Northern Germany. Fungal Ecology 5: $62-72$.

Wu B.M., Subbarao K.V. 2008. Effects of soil temperature, moisture, and burial depths on carpogenic germination of Sclerotinia sclerotiorum and S. minor. Phytopathology 98 (10): 1144-1152.

Wu B.M., Subbarao K.V., Qin Q.-M. 2008. Nonlinear colony extension of Sclerotinia minor and S. sclerotiorum. Mycologia 100 (6): 902-910. 